DOI: $10.19195 / 0524-4544.323 .14$

\title{
ROBERT SUSŁO
}

Uniwersytet Medyczny im. Piastów Śląskich we Wrocławiu e-mail: robert.suslo@umed.wroc.pl

\section{MATEUSZ PAPLICKI}

Uniwersytet Medyczny im. Piastów Śląskich we Wrocławiu e-mail: mateusz.paplicki@umed.wroc.pl

\section{MARZENA KOZAKIEWICZ}

Uniwersytet Medyczny im. Piastów Śląskich we Wrocławiu e-mail: marzena.kozakiewicz@umed.wroc.pl

\section{JAROSŁAW DROBNIK}

Uniwersytet Medyczny im. Piastów Śląskich we Wrocławiu e-mail: jaroslaw.drobnik@umed.wroc.pl

\section{Dokumentacja medyczna elementem bezpieczeństwa pracy ratownika medycznego}

\section{Wstęp}

System ratownictwa medycznego określa się jako

takie rozmieszczenie personelu, urządzeń i sprzętu, które zapewnia skuteczne i skoordynowane działanie systemu w zakresie prewencji i zarządzania zagrożeniami będącymi konsekwencjami nagłych zdarzeń, katastrof, klęsk żywiołowych lub podobnych wydarzeń ${ }^{1}$.

Szczegółowym celem istnienia tego systemu jest zapewnienie przedszpitalnych świadczeń medycznych, udzielanych na miejscu zdarzenia i w czasie transportu oraz szpitalnych świadczeń medycyny ratunkowej realizowanych na oddziałach ratunkowych będących kontynuacją wcześniejszych działań ratowniczych².

1 A. Bem, Organizacja i finansowanie ratownictwa medycznego, „Prace Naukowe Uniwersytetu Ekonomicznego we Wrocławiu" 2013, nr 319, s. 159.

2 Ibidem. 
Medycyna ratunkowa jako specjalność medyczna o charakterze horyzontalnym może być postrzegana jako komplementarna do medycyny rodzinnej, zajmującej się holistyczną, długofalową opieką nad pacjentem ${ }^{3}$.

Obecnie funkcjonująca $\mathrm{w}$ wielu krajach medycyna ratunkowa — lub inaczej medycyna stanów nagłych — oraz organizacja jej systemu wzięły swój początek przede wszystkim z doświadczeń medycyny praktykowanej na polu walki ${ }^{4}$. Związane jest to z faktem, że przez wieki pole bitwy było jednym z głównych miejsc doskonalenia sztuki medycznej, zwłaszcza w dziedzinie chirurgii. Długo w historii ludzkości zasadą było, że bitwy trwały do kilku godzin i kończyły się przeważnie nieco przed zachodem słońca, zaś

o zmroku na pobojowisko nadciągały formacje sanitarne i pracowały do rana. Zdarzały się jednak wypadki, że bitwy toczyły się do samego zmroku. Wówczas ranni musieli spędzić całą noc bez ratunku i bez jakichkolwiek wygód ${ }^{5}$.

Doświadczenia zdobyte w czasie setek większych i mniejszych konfliktów zbrojnych przekonują, iż o prawdopodobieństwie przeżycia pacjenta decyduje sekwencja ściśle powiązanych i następujących po sobie zdarzeń, tzw. ogniwa łańcucha ratunkowego: pierwsza pomoc, kwalifikowana pierwsza pomoc, kwalifikowany transport, szpitalny oddział ratunkowy, specjalistyczne leczenie szpitalne i rehabilitacja. Poszczególne ogniwa owego „łańcucha ratunkowego” mają za zadanie zapewnić pacjentowi w stanie nagłego zagrożenia życia jak najszybszą profesjonalną pomoc.

Około $85 \%$ ofiar śmiertelnych z powodu urazów mogłoby zostać uratowanych pod warunkiem otrzymania właściwej pomocy medycznej w okresie „złotej godziny”, zwanej także „godziną szansy”. Termin ten odnosi się do pierwszych $60 \mathrm{mi}-$ nut, począwszy od momentu powstania urazu do czasu udzielenia specjalistycznego — najczęściej chirurgicznego - leczenia, które taki pacjent optymalnie powinien otrzymać w odpowiednio przystosowanym do tego celu Szpitalnym Oddziale Ratunkowym. Pacjenci z ciężkimi obrażeniami ciała wcześnie opatrzeni w prawidłowy sposób przez odpowiednio wyszkolony personel i niezwłocznie przetransportowani do szpitala mają największe szanse na przeżycie. Obecnie próbuje się również stosować pojęcie ,złotej godziny” w przypadku innych stanów nagłych, niekoniecznie o podłożu urazowym, takich jak zawał mięśnia sercowego czy udar mózgu 6 .

Wzrastające tempo życia i nowoczesne technologie oraz ciągle nie do końca okiełznane siły przyrody wyzwalają zagrożenia zdarzeniami masowymi i katastrofami - stawiają one nowe wyzwania oraz narzucają związane z nimi potrzeby organizacyjne współczesnym społeczeństwom, które aspirują do uzyskania dla

3 J. Drobnik et al., Miejsce i rola praktyki lekarza rodzinnego i medycyny rodzinnej w systemie opieki zdrowotnej, „Family Medicine \& Primary Care Review” 12, 2010, nr 2, s. 159-164.

${ }^{4}$ A. Podlasin, Taktyczne ratownictwo medyczne, Warszawa 2015.

5 S. Wojtkowiak et al., Zarys dziejów wojskowej stużby zdrowia, Warszawa 1974, s. 63.

${ }^{6}$ W. Gaszyński, Intensywna terapia $i$ wybrane zagadnienia medycyny ratunkowej. Repetytorium, Warszawa 2008, s. 115-116. 
swych obywateli stanu jak najbardziej zbliżonego do pełnego bezpieczeństwa. Aby sprostać tym potrzebom, wyodrębniono nowy dział medycyny i ochrony zdrowia, czyli medycynę ratunkową, i jej wykonawczy system organizacyjny, którym w Polsce jest Państwowe Ratownictwo Medyczne ${ }^{7}$. Głównym ich celem jest osiągnięcie jak najwyższych kwalifikacji personelu i generalnej doskonałości organizacyjnej tak, aby można było jak najszybciej podjąć specjalistyczne procedury medycyny ratunkowej wobec pacjenta w nagłym zagrożeniu zdrowotnym co jest konieczne, aby umożliwić mu przetrwanie okresu największego zagrożenia życia, a następnie dać mu szansę na uzyskanie dalszego niezbędnego leczenia specjalistycznego ${ }^{8}$. Z myślą o osiągnięciu optymalnych efektów w tej dziedzinie wyodrębniono w Polsce zawód ratownika medycznego.

Bezpieczeństwo jest dobrem wspólnym, którego jedynym konsumentem jest człowiek $^{9}$; jest ono utożsamiane $\mathrm{z}$,pewnością istnienia i przetrwania oraz potwierdzającym się brakiem poważnych zagrożeń dla egzystencjalnych interesów"10. Bezpieczeństwo jest potrzebą każdego człowieka oraz wypadkową działań zachodzących w wymiarze indywidualnym połączonych z działalnością władz i sprawnie funkcjonujących służb ${ }^{11}$. Dlatego prawidłowe i efektywne działanie służb medycznych, w wysokim stopniu uzależnione w nowoczesnych warunkach od dostępności informacji i jej przesyłania na odległość, jest tak istotne dla zapewnienia bezpieczeństwa, co znajduje odbicie w odpowiednich regulacjach prawnych. W szczególności w Ustawie z dnia 26 kwietnia 2007 r. o zarządzaniu kryzysowym ${ }^{12}$, w której $\mathrm{w}$ art. 3 wymienia się systemy ochrony zdrowia i ratownicze, a także łączności i teleinformatyczne, jako te elementy infrastruktury krytycznej, które odgrywają główną rolę $\mathrm{w}$ zapewnieniu bezpieczeństwa zarówno państwa jako całości, jak i jego poszczególnych obywateli. Z kolei Rozporządzenie Ministra Zdrowia z dnia 9 listopada 2015 r. w sprawie rodzajów, zakresu i wzorów dokumentacji medycznej oraz sposobu jej przetwarzania ${ }^{13}$, wydane na podstawie art. 30 Ustawy z dnia 6 listopada 2008 r. o prawach pacjenta i Rzeczniku Praw Pacjenta ${ }^{14}$ — które szczegółowo i całościowo reguluje zagadnienia prowadzenia dokumentacji medycznej w jednostkach podległych Ministrowi Zdrowia — stanowi w § 1, iż dokumentacja

7 J. Jakubaszko, M. Gruszka, Organizacja i możliwości ratownictwa medycznego w zabezpieczeniu potrzeb spolecznych, [w:] Katastrofy — organizacja badań i specyfika ekspertyz a potrzeby społeczne $i$ wymiaru sprawiedliwości, Warszawa 2010, s. 77.

8 J. Jakubaszko, M. Gruszka, Medycyna ratunkowa - ratownictwo medyczne a bezpieczeństwo publiczne, [w:] Bezpieczeństwo wewnętrzne w działaniach nowej administracji publicznej, red. A. Chajbowicz, T. Kocowski, Wrocław 2009, s. 51.

9 J. Boć, O bezpieczeństwie wewnętrznym, [w:] Bezpieczeństwo wewnętrzne..., s. 20.

10 J. Kukułka, Narodziny nowych koncepcji bezpieczeństwa, [w:] Bezpieczeństwo międzynarodowe w Europie Środkowej po zimnej wojnie, red. J. Kukułka, Warszawa 1994, s. 40-41.

11 M. Lisicki, Zarzadzanie bezpieczeństwem publicznym, Warszawa 2011, s. 23.

12 Dz.U. z 2007 r. Nr 89, poz. 590 ze zm.

13 Dz.U. z 2015 r. poz. 2069.

14 Dz.U. z 2009 r. Nr 52, poz. 417 ze zm. 
medyczna prowadzona jest aktualnie w postaci elektronicznej lub papierowej. Jednocześnie Strategia Bezpieczeństwa Narodowego Rzeczpospolitej Polskiej z roku $2014^{15}$ jeden z celów strategicznych traktuje jako zapewnienie bezpiecznego funkcjonowania państwa w cyberprzestrzeni, gdyż wzrastający stopień uzależnienia różnych dziedzin życia, w tym medycyny, od rozwiązań cyfrowych i elektronicznych systemów łączności sprawia, że zakłócenia ich funkcjonowania coraz poważniej zaburzają funkcjonowanie jednostek i przedsiębiorstw, a nawet całych społeczeństw i organizmów państwowych. Pośród świeżych zagrożeń wynikających z ekspansji nowych technologii znajdują się przeniesione w wirtualną, informatyczną rzeczywistość dobrze znane do tej pory patologiczne zjawiska, opatrywane w literaturze dla odróżnienia od tradycyjnych przedrostkiem „cyber-”: cyberprzestępczość, cyberterroryzm, cyberszpiegostwo, cyberkonflikty oraz cyberwojna, przy czym różnica pomiędzy dwoma ostatnimi leży — odpowiednio — w zaangażowaniu lub braku zaangażowania w konfrontację podmiotów niebędących państwami.

\section{Materiał i metody}

Dokonano analizy dogmatyczno-prawnej wynikających z aktualnego stanu prawnego w Polsce obowiązków ratowników medycznych związanych z prowadzeniem przez nich dokumentacji medycznej, ze szczególnym uwzględnieniem regulacji dotyczących sposobu przetwarzania informacji medycznej przez ratowników medycznych, charakterystyki wypełnianych przez nich dokumentów medycznych oraz praktycznych ograniczeń funkcji dowodowej tych dokumentów $\mathrm{w}$ różnych postępowaniach prawnych.

\section{Dokumentacja medyczna $\mathrm{w}$ pracy ratownika medycznego}

Dokumentacja medyczna systemu ratownictwa medycznego z założenia ma ilustrować aktywność jednostek przedszpitalnych, umożliwić ocenę jakości funkcjonowania systemu państwowego ratownictwa medycznego oraz stwarzać racjonalne wskazówki dla płatnika finansującego działanie systemu w jego fazie przedszpitalnej ${ }^{16}$.

15 Strategia Bezpieczeństwa Narodowego Rzeczpospolitej Polskiej, Warszawa 2014, https:// www.bbn.gov.pl/ftp/SBN\%20RP.pdf (dostęp: 18.07.2017).

16 Stanowisko Polskiego Towarzystwa Medycyny Ratunkowej z dnia 14 lipca 2015 r. w sprawie nowelizacji Rozporządzenia Ministra Zdrowia z dnia 21 grudnia 2010 r. w sprawie rodzaju i zakresu dokumentacji medycznej oraz sposobu jej przetwarzania, Wrocław 2015, s. 1. 
Zgodnie z art. 11 Ustawy z dnia 8 września 2006 r. o Państwowym Ratownictwie Medycznym ${ }^{17}$ wykonywanie zawodu ratownika medycznego polega na realizacji, wedle wskazań aktualnej wiedzy medycznej oraz z należytą starannością, zadań zawodowych, do których w szczególności należą: udzielanie świadczeń zdrowotnych, w tym medycznych czynności ratunkowych, samodzielnie lub pod nadzorem lekarza; zabezpieczanie osób znajdujących się w miejscu zdarzenia oraz podejmowanie działań zapobiegających zwiększeniu liczby osób w stanie nagłego zagrożenia zdrowotnego; transportowanie osób w stanie nagłego zagrożenia zdrowotnego; udzielanie wsparcia psychicznego w sytuacji powodującej stan nagłego zagrożenia zdrowotnego oraz edukacja zdrowotna i promocja zdrowia.

Zadania zawodowe mogą być realizowane przez ratowników medycznych w bardzo zróżnicowanych i szerokich ramach instytucjonalnych, w szczególności: w podmiotach leczniczych; ratownictwie górskim i narciarskim; ratownictwie wodnym; ratownictwie górniczym; morskiej służbie poszukiwania i ratownictwa; w niebędących podmiotami leczniczymi: jednostkach podległych ministrowi właściwemu do spraw obrony narodowej oraz w jednostkach antyterrorystycznych podległych ministrowi właściwemu do spraw wewnętrznych; w jednostkach ochrony przeciwpożarowej; na lotniskach; w podmiotach leczniczych zabezpieczających imprezy masowe; w ramach wykonywania transportu sanitarnego; w izbach wytrzeźwień; a także w charakterze dyspozytora medycznego. W ramach udzielania świadczeń zdrowotnych innych niż medyczne czynności ratunkowe ratownik medyczny wykonuje zlecenia określone w dokumentacji medycznej.

Ratownik medyczny ma prawo wglądu do dokumentacji medycznej oraz do uzyskania od pozostałych przedstawicieli zawodów medycznych - czyli lekarza, felczera, pielęgniarki lub położnej — informacji o stanie zdrowia pacjenta, rozpoznaniu, proponowanych metodach diagnostycznych, leczniczych, rehabilitacyjnych, zapobiegawczych i dających się przewidzieć następstwach podejmowanych działan, w zakresie niezbędnym do udzielanych przez siebie świadczeń zdrowotnych. Sam ratownik medyczny dokumentuje natomiast świadczenia zdrowotne udzielane przez siebie w ramach realizacji zadań zawodowych - lecz także uzasadnienie przyczyny ewentualnego niepodjęcia lub odstąpienia od medycznych czynności ratunkowych albo udzielania świadczeń zdrowotnych, co jest dopuszczalne po dokonaniu przez ratownika medycznego oceny stanu pacjenta, o ile nie spowoduje niebezpieczeństwa utraty życia, poważnego uszkodzenia ciała lub ciężkiego rozstroju zdrowia. Z wyjątkiem zadań, w przypadku których dokumentacja medyczna jest regulowana odrębnie — czyli realizowanych przez ratownika medycznego w ramach podmiotów leczniczych ${ }^{18}$, w izbach wytrzeź-

17 Dz.U. z 2006 r. Nr 191, poz. 1410 ze. zm.

18 Por. Rozporządzenie Ministra Zdrowia w sprawie rodzajów, zakresu i wzorów dokumentacji medycznej oraz sposobu jej przetwarzania. Ustawa o prawach pacjenta i Rzeczniku Praw Pacjenta (Dz.U. z 2009 r. Nr 52, poz. 417 ze zm.). 
wień ${ }^{19}$ lub w charakterze dyspozytora medycznego — ratownik medyczny dokonuje odpowiednich wpisów w karcie indywidualnej ratownika medycznego.

Do tych kart, jak i do podmiotów, w których udzielono udokumentowanych w nich świadczeń, znajdują zastosowanie odpowiednie zapisy art. 23-24 oraz art. 26-29 ustawy o prawach pacjenta i Rzeczniku Praw Pacjenta, dotyczące: prawa pacjenta do dostępu do dokumentacji medycznej odnośnie do jego stanu zdrowia oraz udzielonych mu świadczeń medycznych i ochrony danych zawartych w dokumentacji medycznej; obowiązku prowadzenia, przechowywania i udostępniania dokumentacji medycznej oraz zapewnienia ochrony danych w niej zawartych, a także ograniczenia kręgu osób uprawnionych do ich przetwarzania oraz zobowiązania tych osób do zachowania w tajemnicy informacji związanych z pacjentem, a uzyskanych w związku z wykonywaniem przez nie swych zadań, również po śmierci pacjenta; oraz regulujące zagadnienia udostępniania, przechowywania i niszczenia dokumentacji medycznej. Artykuł 11 ustawy o Państwowym Ratownictwie Medycznym bezpośrednio zobowiązuje ponadto ratownika medycznego do informowania pacjenta o jego prawach wynikających z ustawy o prawach pacjenta i Rzeczniku Praw Pacjenta; do obowiązków ratownika medycznego należy także udzielenie pacjentowi lub jego przedstawicielowi ustawowemu albo osobie wskazanej przez pacjenta informacji o stanie zdrowia pacjenta, w zakresie związanym z podejmowaniem medycznych czynności ratunkowych w podstawowym zespole ratownictwa medycznego; oraz do zachowania tajemnicy zawodowej.

Podkreślenia wymagają ogólnie przyjęte generalne zasady prowadzenia dokumentacji medycznej, skonkretyzowane w $\S 4$ rozporządzenia Ministra Zdrowia w sprawie rodzajów, zakresu i wzorów dokumentacji medycznej oraz sposobu jej przetwarzania - wpisu w dokumentacji dokonuje się niezwłocznie po udzieleniu świadczenia zdrowotnego, w sposób czytelny i w porządku chronologicznym; każdy wpis w dokumentacji opatruje się oznaczeniem osoby dokonującej wpisu; wpis sporządzony w dokumentacji nie może być z niej usunięty, a jeżeli został dokonany błędnie, skreśla się go i zamieszcza adnotację o przyczynie błędu oraz datę i oznaczenie osoby dokonującej adnotacji.

Ponadto, zgodnie z art. 11 ustawy o Państwowym Ratownictwie Medycznym, karta indywidualna ratownika medycznego zawiera dane wymienione w art. 25 ustawy o prawach pacjenta i Rzeczniku Praw Pacjenta, czyli: oznaczenie pacjenta pozwalające na ustalenie jego tożsamości; oznaczenie podmiotu udzielającego świadczeń zdrowotnych ze wskazaniem komórki organizacyjnej, w której udzielono świadczeń zdrowotnych; opis stanu zdrowia pacjenta lub udzielonych mu świadczeń zdrowotnych oraz datę sporządzenia zapisów. Na tej podstawie Mi-

19 Por. Ustawa z dnia 26 października 1982 r. o wychowaniu w trzeźwości i przeciwdziałaniu alkoholizmowi (Dz.U. z 1982 r. Nr 35, poz. 230 ze zm.); Rozporządzenie Ministra Zdrowia z dnia 8 grudnia 2014 r. w sprawie izb wytrzeźwień i placówek wskazanych lub utworzonych przez jednostkę samorządu terytorialnego (Dz.U. z 2014 r. poz. 1850). 
nister Zdrowia określił w drodze odpowiedniego rozporządzenia ${ }^{20}$ uniwersalny wzór karty indywidualnej ratownika medycznego.

Mimo planowanej migracji całości dokumentacji medycznej w Polsce do formy jedynie elektronicznej, karta ta została opracowana do użytkowania praktycznie wyłącznie w formie papierowej, na co wskazuje zarówno układ dokumentu, jak i miejsce przewidziane na podpis i pieczęć ratownika medycznego oraz podpis pacjenta lub jego przedstawiciela ustawowego pod formułą potwierdzającą otrzymanie informacji medycznej oraz dotyczącą odmowy zgody na poddanie się świadczeniom medycznym lub przewiezienie do szpitala. Wzór karty indywidualnej ratownika medycznego, stanowiący załącznik do wzmiankowanego rozporządzenia, ma postać zwartego formularza, którego wypełnienie - poza: danymi identyfikującymi pacjenta, ewentualnie także jego przedstawiciela ustawowego; danymi identyfikującymi podmiot udzielający świadczeń medycznych i ratownika medycznego; danymi identyfikującymi świadczenie, w tym miejsce i czas jego udzielenia oraz udokumentowania — w przeważającej części pozycji wymaga tylko: zakreślenia odpowiednich pól wyboru; wpisania ściśle określonych rodzajów informacji, w tym wartości kluczowych parametrów życiowych oraz nazwy, dawki/ilości, drogi podania i czasu zastosowania produktów leczniczych oraz wyrobów medycznych; ewentualnie zamieszczenia w skondensowanej formie danych: uzyskanych z wywiadu, dotyczących opisu interwencji, rozpoznania i zaleceń/uwag.

Należy zaznaczyć, iż działalność medyczna w ogóle, a szczególnie w zakresie medycyny ratunkowej, z uwagi na swą specyfikę stwarza w praktyce liczne utrudnienia w prawidłowym prowadzeniu odpowiedniej dokumentacji, zarówno w formie papierowej, jak i elektronicznej ${ }^{21}$. Trzeba jednocześnie podkreślić, że dokumentacji medycznej sporządzonej przez ratowników medycznych nie omijają wady znane od dawna, aczkolwiek wymieniane typowo w kontekście dokumentów papierowych wypełnianych przez lekarzy ${ }^{22}$; należą do nich zwłaszcza: nieczytelność lub niejednoznaczność zapisów, ich nadmierna skrótowość, chaotyczność lub bezkrytycznie szablonowy charakter, nieprawidłowości lub braki merytoryczne, wynikające nierzadko z opóźnień w sporządzaniu wpisów, albo też nieprawidłowości lub brak uzupełnienia któregokolwiek spośród pozostałych koniecznych elementów formalnych dokumentu medycznego, do których zaliczamy: dane identyfikujące pacjenta, oznaczenie podmiotu i osoby udzielającej świadczenia zdrowotnego oraz datę udzielenia tego świadczenia; zdarzają się także nieuprawnione przeróbki bądź skreślenia albo wręcz zamazanie wpisów,

${ }^{20}$ Rozporządzenie Ministra Zdrowia z dnia 20 kwietnia 2016 r. w sprawie określenia wzoru karty indywidualnej ratownika medycznego (Dz.U. z 2016 r. poz. 576).

21 R. Susło et al., Specyfika ochrony danych w placówkach medycznych, „Family Medicine \& Primary Care Review" 8, 2006, nr 3, s. 778-780.

22 R. Susło, B. Świątek, Ochrona danych medycznych a opiniowanie sądowo-lekarskie, „Archiwum Medycyny Sadowej i Kryminologii” 55, 2005, nr 4, s. 314-318. 
ewentualnie zagubienie, uszkodzenie lub nawet całkowite zniszczenie dokumentu medycznego 23 .

Według art. 26 ustawy o Państwowym Ratownictwie Medycznym ratownik medyczny pracujący w charakterze dyspozytora medycznego wykonuje swoje zadania z wykorzystaniem Sytemu Wspomagania Dowodzenia Państwowego Ratownictwa Medycznego, natomiast art. 27 tej ustawy zobowiązuje go do zbierania i archiwizowania bieżących informacji o zdarzeniach i prowadzonych medycznych czynnościach ratunkowych - w sposób uregulowany szczegółowo w odpowiednim rozporządzeniu Ministra Zdrowia ${ }^{24}$. Zgodnie z art. 25 ustawy o prawach pacjenta i Rzeczniku Praw Pacjenta przepisy o dokumentacji medycznej nie znajdują zastosowania do wymienionych w art. 24b ustawy o Państwowym Ratownictwie Medycznym danych dotyczących treści zgłoszeń alarmowych, w tym do nagrań rozmów telefonicznych, zarejestrowanych w Systemie Wspomagania Dowodzenia Państwowego Ratownictwa Medycznego.

\section{Wnioski}

W przypadku polskiej medycyny ratunkowej, z racji ciągle jeszcze stosunkowo niewielkiego jej uzależnienia od systemów informatycznych, można przyjąć, iż cyberzagrożenia informacji medycznej nie odgrywają obecnie istotnej roli. Poważnym problemem jest natomiast to, że podczas opatrywania nagłych stanów zdrowotnych rozwój wypadków bywa bardzo dynamiczny i z tego powodu niejednokrotnie ratownikom medycznym trudno jest adekwatnie oddać w dokumentacji medycznej przebieg postępowania wobec pacjenta. Mimo ustawowego wymogu niezwłocznego dokonywania zapisów w dokumentacji medycznej, z racji częstego obciążenia równolegle kilkoma pilnymi zadaniami, zwłaszcza związanymi z opieką nad pacjentem znajdującym się w stanie zagrożenia życia, często bieżące uzupełnianie dokumentacji medycznej stanowi dla ratowników medycznych wyzwanie. Dlatego należy przyjąć, iż w praktyce niekiedy wpisy z konieczności dokonywane są przez ratowników medycznych w różnym czasie po zakończeniu danej interwencji medycznej. W takich przypadkach zgodność zawartości dokumentacji medycznej z rzeczywistym przebiegiem zdarzeń bywa w różnym stopniu niepełna, a wpisy mogą nie odzwierciedlać w pełni stwierdzonego stanu zdrowia pacjenta lub charakteru i toku podjętych względem niego czyn-

23 J. Drobnik et al., Nieprawidłowości dotyczace zewnętrznej dokumentacji medycznej, „Przewodnik Lekarza" 1, 2008, s. 270-274; R. Susło et al., Nieprawidłowości dotyczace wewnętrznej dokumentacji medycznej, „Przewodnik Lekarza” 1, 2008, s. 275-280.

24 Rozporządzenie Ministra Zdrowia z dnia 10 stycznia 2014 r. w sprawie ramowych procedur przyjmowania wezwań przez dyspozytora medycznego i dysponowania zespołami ratownictwa medycznego (Dz.U. z 2014 r. poz. 66). 
ności diagnostycznych bądź leczniczych. Jedynie częściowym rozwiązaniem tego problemu może być automatyczne rejestrowanie przebiegu części czynności medycznych, np. elementów akcji resuscytacyjnej, przez odpowiednio wyposażony w rejestratory sprzęt medyczny.

Nabiera to szczególnego znaczenia, biorąc pod uwagę, iż zawartość dokumentacji medycznej ma istotny wpływ zarówno na sposób dalszego leczenia pacjenta po ustabilizowaniu funkcji życiowych i przekazaniu do szpitala, jak i na adekwatność ewentualnej późniejszej oceny prawidłowości postępowania ratownika medycznego, w tym na potrzeby postępowania przed sądami ${ }^{25}$. Odpowiedzialność personelu medycznego za błąd medyczny może mieć bowiem charakter karny, cywilny, zawodowy lub pracowniczy ${ }^{26}$. O podejrzenia wystąpienia błędu medycznego nietrudno wobec faktu, iż medycyna stanów nagłych ze względu na swą specyfikę - na którą składa się m.in. częsta konieczność szybkiego podejmowania trafnych decyzji w wysoce nieprzewidywalnych warunkach - wymaga od ratowników medycznych optymalnego działania mimo znacznego obciążenia stresem.

Wobec wymuszonej - obowiązującymi z racji regulacji ustawowych wzorami dokumentów - lapidarności wpisów w dokumentacji medycznej prowadzonej przez ratowników medycznych szczególnej wagi nabiera zachowywanie przez nich najwyższej staranności przy sporządzaniu wpisów, gdyż w sytuacji zaistnienia wątpliwości dotyczących prawidłowości postępowania medycznego wpisy te odgrywają kluczową rolę w jego ocenie. Powyższy wymóg winien być uwzględniany zarówno w ramach regularnego bieżącego nadzoru nad pracą ratowników medycznych, jak i w ich przed- i podyplomowym, a zwłaszcza ustawicznym szkoleniu.

\title{
Medical documents as element of paramedic's working safety
}

\author{
Summary
}

Emergency medicine serves providing both pre-hospital medical services directly at emergency site and during transportation, and hospital emergency services at hospital emergency wards that result from previous rescue activities. Filling in medical documents is a key element of paramedic's activities indifferent of employing institution; as in Poland they are kept predominantly in paper form a cyberattack risk is low in this case. Keeping correct and proper medical records plays key role in

25 R. Susło et al., Sposób sporządzania dokumentów medycznych jako przyczyna błędu opiniodawczego, „Family Medicine \& Primary Care Review” 11, 2009, nr 3, s. 506-508.

26 J. Trnka et al., Karne i cywilne konsekwencje błędów medycznych, „Badania Naukowe” (Wydawnictwo Wyższej Szkoły Umiejętności w Kielcach) 2, 2007, nr 21, s. 59. 
ensuring both patient's medical safety and paramedic's formal and legal safety, including cases of suspected medical error. It is troublesome because of characteristics of paramedic's job that include in particular multitasking, time and responsibility pressure and resulting in stress.

Keywords: emergency medicine, medical document, medical law, forensic medicine. 